ISSN Print : 1411 - 951 X, ISSN Online : 20503-1716

Jurnal Ergonomi Indonesia

(The Indonesian .Journal of Ergonomic)

Vol.3, No.2 : 1 Juli-Desember 2017

\title{
REDESAIN PEGANGAN TABUNG SINAR-X YANG ERGONOMIS DI RADIOLOGI RSUP SANGLAH MENURUNKAN KELUHAN MUSKULOSKELETAL, MENGURANGI KELELAHAN UMUM DAN MENINGKATKAN KECEPATAN PEMERIKSAAN
}

\author{
${ }^{1}$ Susanta, I Putu Adi, ${ }^{2}$ Purnawati, Susy. ${ }^{3}$ Adiatmika, I Putu Gede \\ Mahasiswa Program Pascasarjana Ergonomi Fisiologi KerjaUniversitas Udayana \\ Dosen Program Pascasarjana Ergonomi Fisiologi KerjaUniversitas Udayana \\ Guru Besar Program Pascasarjana Ergonomi Fisiologi KerjaUniversitas Udayana
}

\begin{abstract}
Abstrak
Instalasi radiologi adalah unit pelayanan penunjang medis dalam suatu fasilitas kesehatan yang memiliki fungsi sebagai sarana penegakan diagnosa pasien. Di RSUP Sanglah terdapat 5 unit sub bagian radiologi antara lain Radiologi Central, IRD, Wing Amerta, Ruang Bedah Central dan Ruang Cath Lab yang seluruhnya memiliki tujuan memberikan nilai diagnostik yang bermutu kepada pasien dan masyarakat. Masalah yang terjadi dalam unit radiologi adalah timbulnya keluhan muskuloskeletal yang berhubungan dengan pekerjaan, peningkatan kelelahan umum pada pekerja, serta turunnya kecepatan pemeriksaan oleh radiografer dalam pelayanan. Hal ini dapat disebabkan oleh ketidaksesuaian antara alat kerja dengan penggunanya.
\end{abstract}

Telah dilakukan penelitian dengan intervensi redesain pegangan tabung sinar-X melalui pertimbangan antropometri pengguna bertujuan mengetahui seberapa besar pengaruh perbaikan desain pegangan tabung sinar-X terhadap keluhan muskuloskeletal, kelelahan umum dan peningkatan kecepatan pemeriksaan oleh radiografer. Data antropometri subjek digunakan sebagai dasar untuk meredesain pegangan tabung sinar$\mathrm{X}$.

Rancangan penelitian menggunakan Treatment By Subject Designs dengan besar sampel 12 orang yang menjadi kelompok kontrol sekaligus menjadi kelompok intervensi. Subjek diberi perlakuan berupa redesain pegangan tabung sinar-X atau pegangan yang telah diperbaiki bentuk dan desainnya lebih ergonomis disesuaikan dengan antropometri tubuh subjek. Keluhan muskuloskeletal dinilai dengan kuesioner Nordic Body Map dari NIOSH Japan, gangguan kelelahan umum dengan 30 item kelelahan umum, dan kecepatan pemeriksaan oleh radiografer diperoleh dengan cara mengukur waktu pemeriskaan pada saat melakukan pelayanan radiologi terhadap jumlah pemeriksaan yang dilakukan. Dilakukan uji Shapiro - Wilk untuk mengetahui normalitas data pada tingkat kemaknaan $(\alpha=0,05)$. Uji komparasi beda efek antara sebelum perbaikan dan sesudah perbaikan desain terhadap keluhan muskuloskeletal, kelelahan umum dan kecepatan pemeriksaan menggunakan paired t-test pada tingkat kemaknaan $\alpha=0,05$ 
ISSN Print : 1411 - 951 X, ISSN Online : 20503-1716

Jurnal Ergonomi Indonesia

(The Indonesian .Journal of Ergonomic)

Vol.3, No.2 : 1 Juli-Desember 2017

Diperoleh hasil bahwa pada kelompok intervensi penggunaan pegangan tabung sinar-X yang telah diredesain dapat menurunkan keluhan muskuloskeletal secara bermakna $(\mathrm{p}<0,05)$ sebesar $10,42 \%$, mengurangi kelelahan umum secara bermakna sebesar 22,38 \% (p<0,05) dan meningkatkan kecepatan pemeriksaan sebesar $12.50 \%$ $(\mathrm{p}<0,05)$. Dengan demikian dapat disimpulkan bahwa perbaikan desain pegangan tabung sinar-X dapat menurunkan keluhan muskuloskeletal, mengurangi kelelahan umum dan meningkatkan kecepatan pemeriksaan oleh radiografer di RSUP Sanglah Denpasar.

Kata Kunci : Desain, Pegangan, Tabung Sinar-X, Keluhan Muskuloskeletal, Kelelahan Kerja, Kecepatan Pemeriksan Raidologi. 
ISSN Print : 1411 - 951 X, ISSN Online : 20503-1716

Jurnal Ergonomi Indonesia

(The Indonesian .Journal of Ergonomic)

Vol.3, No.2 : 1 Juli-Desember 2017

\title{
REDESIGNED ERGONOMIC X-RAY TUBE HANDLE AT RADIOLOGY \\ DEPARTEMENT OF SANGLAH HOSPITAL REDUCES MUSCULOSKELETAL \\ DISCOMFORT, GENERAL FATIGUE AND INCREASES EXAMINATION \\ SPEED
}

\begin{abstract}
Radiology Installation is a unit of medical support services in a health facility that has a function as a means of patient diagnosis. In RSUP Sanglah there are 5 units of radiology sub-section such as Central Radiology, IRD, Wing Amerta, Central Surgery Room and Cath Lab Room which all have a goal of providing quality diagnostic value to patients and society. Problems occurring within the radiology unit are the incidence of work-related musculoskeletal complaints, increased general fatigue in workers, as well as decreased speed of examination by radiographers in service. This can be caused by a mismatch between the work tool and its users.
\end{abstract}

Research has been conducted with intervention of redesign of $X$-ray tube handling through user anthropometry aims to know how big the effect of X-ray tube grip design improvement to musculoskeletal complaints, general fatigue and increased examination speed by radiographer. The subject anthropometry data is used as the basis for redesigning the X-ray tube handle.

The design of the study using Treatment By Subject Designs with a large sample of 12 people who became the control group as well as the intervention group. Subjects were subjected to redesigned $X$-ray tube handles or grips that have been improved in shape and design more ergonomically adapted to the anthropometry of the subject body. Musculoskeletal complaints were assessed with Nordic Body Map questionnaires from NIOSH Japan, generalized fatigue disorder with 30 general fatigue items, and the examination speed by radiographers was obtained by measuring the time of the radiologic treatment on the number of checks performed. Shapiro - Wilk test was performed to determine the normality of data at significance level $(\alpha=0,05)$. Differential comparative test between pre-repair and post-design improvement of musculoskeletal complaints, general fatigue and speed of examination using paired $t$ test at significance level $\alpha=0.05$

It was found that in the intervention group the use of redesigned $X$-ray tubes could significantly decrease musculoskeletal complaints $(p<0.05)$ by $10.42 \%$, significantly reducing general fatigue by $22.38 \%(p<0.05)$ and increased the examination rate by $12.50 \%$ ( $p$ <0.05). Thus it can be concluded that the improved X-ray tube handle design can decrease musculoskeletal complaints, reduce general fatigue and increase the speed of inspection by radiographers at Sanglah Hospital Denpasar.

Keywords: Design, Handrail, X-ray Tubes, Musculoskeletal Complaints, Work Fatigue, Examination Time Speed, 
ISSN Print : 1411 - 951 X, ISSN Online : 20503-1716

Jurnal Ergonomi Indonesia (The Indonesian .Journal of Ergonomic)

\section{Pendahuluan}

Peran sinar-X tidak terlepas dari peran radiografer yaitu tenaga medis yang bertugas mengoperasikan alat radiologi. Interaksi radiografer dengan alat menentukan keberhasilan peran sinar-X dalam bidang kesehatan, oleh karena itu kondisi radiografer hendaklah selalu optimal. Dalam survey Soceity of Radiographers (SOR) tahun 2000 terungkap bahwa $70 \%$ dari seluruh radiografer melaporkan gejala sakit dan keluhan otot dan skeletal yang dipercaya berhubungan dengan pekerjaan (Arrowsmith 2000). Jika dibandingkan dengan kemungkinan pada seorang pekerja, kejadian sakit pada leher dan lengan pada populasi umum sebesar $70 \%$ dan batas kemungkinan 13\% dan 22,5\% (Feather 2001). Jika musculoskeletal disorders (MSD) tidak dapat dikenali atau diobati secepatnya atau penyebabnya tidak dapat ditemukan, hal ini dapat menimbulkan penghentian kerja karena sakit, kehilangan pekerja yang terlatih dan berpengalaman serta pengeluaran tambahan untuk pencarian dan pengangkatan pekerja baru (Russo, et al. 2002).

Instalasi radiologi adalah unit pelayanan penunjang medis dalam suatu fasilitas kesehatan yang memiliki fungsi sebagai sarana penegakan diagnosa pasien. Di RSUP Sanglah terdapat 5 unit sub bagian radiologi antara lain Radiologi Central, IRD, Wing Amerta, Ruang Bedah Central dan Ruang Cath Lab yang seluruhnya memiliki tujuan memberikan nilai diagnostik yang bermutu kepada pasien dan masyarakat. Masalah yang terjadi dalam unit radiologi adalah timbulnya keluhan muskuloskeletal yang berhubungan dengan pekerjaan, peningkatan kelelahan umum pada pekerja, serta turunnya kecepatan pemeriksaan oleh radiografer dalam pelayanan. Hal ini dapat disebabkan oleh ketidaksesuaian antara alat kerja dengan penggunanya. Keluhan yang muncul pada radiografer adalah akibat gerakan tubuh yang tidak fisiologis seperti mengangkat beban, memuntir tubuh, menjinjit, menarik, dan mendorong ketika bekerja memberikan pelayanan radiologi kepada pasien. Gerakan tubuh tersebut terjadi ketika menggerakan tabung sinar-X kearah objek atau pasien, juga terjadi ketika meletakan alat bantu pemeriksaan di bawah dan sekitar objek foto berupa mengangkat tubuh pasien, memposisikan alat atau organ yang akan di foto. Gerakan yang tidak fisiologi tersebut jika dilakukan secara berulang - ulang, dalam tempo singkat akan memberikan dampak bagi kondisi tubuh pekerja, dapat berupa keluhan MSD atau bahkan timbul kelainan menetap. Kondisi ini dijumpai juga di RSUP Sanglah.

Kondisi yang belum ergonomis di radiologi RSUP Sanglah antara lain terdapat sikap kerja yang tidak alamiah seperti membungkuk, menjinjit, mengangkat, mendorong, dan memuntir tubuh. Radiografer melakukan sikap kerja membungkuk dalam memposisikan pasien untuk dilakukan pemeriksaan radiologi, mengangkat pasien dan memasukan kaset atau film radiologi, menjinjit dalam meraih tabung sinar-X lalu didorong atau ditarik untuk diletakan pada objek yang akan disinari. Bekerja dengan sikap kerja tidak alamiah akan menimbulkan cedera dan gangguan muskuloskeletal jika dilakukan terus menerus, berulang - ulang, dalam jangka waktu lama. Akibat yang timbul 
ISSN Print : 1411 - 951 X, ISSN Online : 20503-1716

Jurnal Ergonomi Indonesia (The Indonesian .Journal of Ergonomic)

dari kondisi alat kerja, sikap, waktu dan volume kerja seperti diatas adalah muncul keluhan-keluhan pada radiografer yang dapat menimbulkan penyakit muskuloskeletal dan menurunnya kecepatan radiografer dalam melakukan pemeriksaan radiologi. Apabila hal ini menjadi kebiasaan yang berlanjut menjadi budaya kerja yang tidak aman dan tidak sehat maka dikawatirkan akan membawa pengaruh yang kurang baik terhadap lingkungan kerja. Tuntutan tugas, kondisi lingkungan dan organisasi kerja yang kurang proposional dapat menimbulkan gangguan kesehatan, kelelahan, penurunan kewaspadaan, peningkatan angka kecelakaan kerja dan pada akhirnya menyebabkan terjadinya penurunan efisiensi dan kecepatan pemeriksaan kerja.

Untuk itu dilakukan penelitian dengan intervensi redesain pegangan tabung sinar$\mathrm{X}$ melalui pertimbangan antropometri pengguna bertujuan mengetahui seberapa besar pengaruh perbaikan desain pegangan tabung sinar-X terhadap keluhan muskuloskeletal, kelelahan umum dan peningkatan kecepatan pemeriksaan oleh radiografer. Data antropometri subjek digunakan sebagai dasar untuk meredesain pegangan tabung sinar-X.

\section{Metode Penelitian}

Penelitian ini merupakan penelitian eksperimental, menggunakan rancangan sama subjek (treatment by subject design) Penelitian di lakukan instalasi radiologi RSUP Sanglah Denpasar di jalan Diponegoro Denpasar, selama 4 minggu pada bulan Juli - Agustus 2017. Populasi sebanyak 52 radiografer dengan sampel penelitian sebanyak 12 radiografer instalasi radiologi RSUP Sanglah Denpasar dibuktikan dengan kepemilikan
Vol.3, No.2 : 1 Juli-Desember 2017

kartu identitas karyawan sebagai kelompok kontrol sekaligus menjadi kelompok intervensi. Subjek diberi perlakuan berupa redesain pegangan tabung sinar- $X$ atau pegangan yang telah diperbaiki bentuk dan desainnya lebih ergonomis disesuaikan dengan antropometri tubuh subjek. Alat yang digunakan antara lain kuesioner Nordic Body Map dengan 4 skala likert digunakan untuk menginterpretasikan keluhan otot skeletal. Kuesioner 30 daftar pertanyaan dengan 4 skala likert digunakan untuk identifikasi kelelahan umum. Stopwatch untuk mengukur kecepatan pemeriksaan dan kamera Digital resolusi 5 megapixel untuk dokumentasi yang terinstall pada tablet phone Samsung Note 8 buatan Korea, Antropometer merek Super buatan Jepang, untuk mengukur data atropometri dengan ketelitian $0,1 \mathrm{~mm}$, meteran kecil dengan kemampuan ukur 5 meter memiliki ketelitian $0,1 \mathrm{~cm}$ digunakan untuk mengukur alat kerja. Sling Termometer, dengan ketelitian $0,5^{\circ}$ digunakan untuk mengukur kondisi mikroklimat yang meliputi suhu basah,suhu kering dan ISBB. Luxmeter dengan ketelitian 0,1 lux untuk mengukur intensitas penerangan. Alat tulis menulis untuk mencatat hasil penelitian.

Data dianalisis menggunakan program SPSS (Statistical Package for The Social Science) 16 for windows. Analisis data menggunakan statistik inferensial (Nasir, 1988). Analisis deskriptif sehingga diperoleh rerata simpang baku dan rentangan dari data variabel penelitian. Sebagai prasyarat uji statistik parametrik dilakukan uji Shapiro - Wilk untuk menguji normalitas data pada tingkat kemaknaan $(\alpha=0,05)$. Uji Komparasi data keluhan muskuloskeletal, kelelahan umum 
ISSN Print : 1411 - 951 X, ISSN Online : 20503-1716

Jurnal Ergonomi Indonesia

(The Indonesian .Journal of Ergonomic)

Vol.3, No.2 : 1 Juli-Desember 2017

dan produksi antara sebelum perlakukan dan sesudah perlakukan terhadap variabel subjektif dan kecepatan pemeriksaan kerja menggunakan paired-t test pada tingkat kemaknaan $\alpha=0,05$.

\section{Hasil dan Pembahasan}

Hasil analisis terhadap 12 radiografer RSUP Sanglah Denpasar, menunjukan bahwa rerata umur adalah $30,56 \pm 4,21$ tahun dengan rentangan umur subjek yang telah ditetapkan, yaitu antara 19 sampai 45 tahun. Berkaitan dengan umur, Manuaba (1990) menyatakan bahwa kapasitas fisik

sesorang berbanding langsung sampai batas tertentu dengan umur, dan mencapai puncaknya pada umur 25 tahun. Menurut Nala (1994), pengaruh kemampuan fisiologis otot berada pada rentangan 2030 tahun. Disimpulkan semua subjek penelitian sedang dalam kapasitas kemampuan fisik optimal. Tingkat keluhan muskuloskeletal, kelelahan umum, yang dialami subjek pada penelitian ini serta kecepatan pemeriksaan memang berasal dari kondisi kerja subjek. Seluruh hasil disajikan pada tabel 3.1.

Tabel.3.1 Data hasil penelitian

\begin{tabular}{|c|c|c|c|c|c|c|}
\hline \multirow[t]{2}{*}{ Variable } & \multicolumn{2}{|c|}{$\begin{array}{l}\text { Sebelum } \\
\text { perbaikan }\end{array}$} & \multicolumn{2}{|c|}{$\begin{array}{l}\text { Sesudah } \\
\text { perbaikan }\end{array}$} & \multirow{2}{*}{$\begin{array}{l}\text { Nilai } \\
\mathbf{t}\end{array}$} & \multirow{2}{*}{$\begin{array}{l}\text { Nilai } \\
\mathbf{P}\end{array}$} \\
\hline & Rerata & SB & Rerata & SB & & \\
\hline Suhu basah $\left({ }^{\circ} \mathrm{C}\right)$ & 20,72 & 0,66 & 20,47 & 0,51 & 0,802 & 0,443 \\
\hline Suhu kering $\left({ }^{\circ} \mathrm{C}\right)$ & 24,89 & 0,52 & 25,17 & 0,56 & 1,000 & 0,343 \\
\hline $\begin{array}{l}\text { Kelembaban rel. } \\
(\%)\end{array}$ & 70,47 & 2,79 & 69,56 & 2,90 & 0,361 & 0,726 \\
\hline $\begin{array}{l}\text { Int.Kebisingan } \\
(\mathrm{dBA})\end{array}$ & 69,39 & 0,99 & 69,47 & 0,81 & $-17,05$ & 0,122 \\
\hline $\begin{array}{l}\text { Int. Penerangan } \\
\text { (lux) }\end{array}$ & 59,64 & 1,15 & 59,58 & 0,87 & 19,20 & 0,087 \\
\hline $\begin{array}{l}\text { Keluhan Mus. } \\
\text { Sblm }\end{array}$ & 36,93 & 3,64 & 36,50 & 3,65 & $-20,22$ & 0,221 \\
\hline $\begin{array}{l}\text { Keluhan Mus. } \\
\text { Ssdh }\end{array}$ & 43,56 & 3,86 & 38,56 & 3,5 & $-12,13$ & 0,001 \\
\hline Selisih Kel. Mus. & 6,63 & 0,22 & 2,06 & 0,15 & 8,09 & 0,000 \\
\hline $\begin{array}{l}\text { Kelelahan } \\
\text { Sebelum }\end{array}$ & 34,58 & 3,27 & 33,88 & 3,65 & $-18,91$ & 0.632 \\
\hline Kelelahan Sesudah & 59,29 & 2,74 & 45,32 & 3,5 & $-11,34$ & 0.001 \\
\hline Selisih kelelahan & 24,71 & 0,22 & 11,44 & 0,15 & 7,57 & 0,000 \\
\hline $\begin{array}{l}\text { Kecepatan priksa } \\
\text { (det) }\end{array}$ & 248,18 & 8,84 & 217,23 & 6,52 & 37,79 & 0.001 \\
\hline
\end{tabular}

Tinggi dan berat badan memiliki pengaruh terhadap kelincahan serta penampilan seseorang selama melakukan pekerjaan (Pheasant,1986). Menurut Aryatmo (1981) berat badan yang melebihi perbandingan tinggi badan dengan berat badan ideal akan melebihi kemampuan daya penopang tubuh sehingga bisa menimbulkan nyeri pada lutut dan pergelangan kaki. Beban berlebihan yang berlangsung lama merapatkan jarak ruas tulang punggung, memperbesar tekanan pada jaringan sehingga menimbulkan rasa sakit dan sering terjadi pada kelompok umur 20-30 tahun (Sastrowinoto,1985). Rerata tinggi badan subjek dalam penelitian ini adalah 
ISSN Print : 1411 - 951 X, ISSN Online : 20503-1716

Jurnal Ergonomi Indonesia (The Indonesian .Journal of Ergonomic)

$170,81 \pm 6,66 \mathrm{~cm}$. Sedangkan berat badan subjek pada penelitian ini dengan rerata

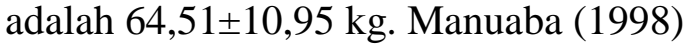
berat badan normal adalah tinggi badan dikurangi 100, dan berat badan ideal adalah berat badan normal $\pm 10 \%$. Berdasarkan rumusan tersebut dapat dinyatakan bahwa berat badan subjek masih termasuk dalam berat badan yang ideal.

Data antropometri subjek digunakan sebagai dasar untuk mendesain alat/pegangan tabung sinar-X. Dari analisis data antropometri tangan subjek didapatkan persentil 5 panjang tangan 18 $\mathrm{cm}$, yang dimaksud adalah untuk mendesain pegangan tabung sinar-X. Diameter genggaman pegangan tabung sinar-X di Instalasi Radiologi RSUP Sanglah Denpasar adalah $4 \mathrm{~cm}$. Ukuran gagang pegangan tabung sinar-X sebelum perbaikan tebalnya $1 \mathrm{~cm}$ dengan panjang \pm $10 \mathrm{~cm}$. Penggunaan alat tersebut mengakibatkan sikap kerja tidak alamiah pada tangan, sehingga menimbulkan rasa sakit pada telapak tangan dan jari-jari. Keluhan paling besar pada saat mengoperasikan tabung sebelum perbaikan terjadi pada telapak dan pergelangan tangan yang disebabkan oleh bentuk pegangan yang kecil.

Ukuran pegangan tabung setelah perbaikan diameternya $4 \mathrm{~cm}$ dengan perbaikan desain. Ukuran gagang alat tersebut sesuai dengan diameter genggaman tangan radiografer. Dengan adanya perbaikan pegangan disertai perbaikan desain yang sesuai dengan antropometri tangan radiografer, terjadi penurunan keluhan muskuloskeletal dan kelelahan umum terhadap radiografer yang melakukan pelayanan radiologi kepada
Vol.3, No.2 : 1 Juli-Desember 2017

pasien sehingga radiografer merasa lebih nyaman pada saat melakukan pemeriksaan radiologi. Berdasarkan wawancara dengan 12 radiografer RSUP Sanglah yang menjadi subjek penelitian, mereka menyatakan bahwa dengan perbaikan desain pegangan tabung sinar-X dirasakan lebih nyaman pada saat digunakan. Dalam penelitian Radiawan (2008) tentang alat penyisitan pandan pada perajin tikar pandan di Desa Tumbu Karangasem, dari analisis antropometri tangan subjek didapatkan persentil 5 panjang tangan 15 $\mathrm{cm}$ dan diperoleh diameter gagang alat penyisitan adalah 30mm. Pheasant (1991) menganjurkan ukuran pegangan $35 \mathrm{~mm}$ dan Nala (1992) menyarankan diameter pegangan $25 \mathrm{~mm}-35 \mathrm{~mm}$ seperti alat genggam yang lebih besar, seperti pisau, sabit, palu dan sebagainya mempunyai diameter yang ideal adalah seluas lingkaran yang dibentuk oleh jari tangan dengan telapak tangan dan ibu jari, dimana ujung jari tengah menyentuh pangkal sampai ruas pertama ibu jari. Besarnya diameter genggaman ini adalah berkisar 2,5-3,5 $\mathrm{cm}$, sedangkan panjang pegangan ditentukan dengan perhitungan 95 persentil $90 \mathrm{~mm}$, maka panjang dari pegangan $\pm 120 \mathrm{~mm}$. Alat-alat yang lebih besar lagi seperti cangkul, palu, penumbuk, kapak dan lainnya, besar diametemya maksimal ujung jari tengah bertemu dengan ujung ibu jari. Ukuran Maksimumnya adalah dengan garis tengah lingkar 7,5 cm. Sutajaya (2006), data antropometri tangan dimanfaatkan untuk mendesain pegangan, alat-alat tangan untuk mencapai kenyamanan.

Lingkungan kerja yang meliputi kebisingan, intensitas penerangan dan mikroklimat yang terdiri dari suhu basah, suhu kering dan kelembaban udara relatif 
ISSN Print : 1411 - 951 X, ISSN Online : 20503-1716

Jurnal Ergonomi Indonesia (The Indonesian .Journal of Ergonomic)

yang diukur pada saat sebelum mulai aktivitas jaga, pertengahan waktu jaga dan setelah waktu jaga malam berakhir yaitu mulai pukul 20.00, berakhir pukul 08.00 Wita. Manuaba (1998) menyatakan bahwa nilai ambang batas dari suhu udara untuk pekerja adalah $33^{\circ} \mathrm{C}$ dan kelembaban relatif pekerja orang Indonesia yang masih tergolong nyaman adalah $70 \%-80 \%$.

Sedangkan intensitas penerangan tergantung dari jenis pekerjaan, pekerja yang presisi memerlukan intensitas yang lebih tinggi dari pada pekerja yang tidak memerlukan ketelitian dengan penerangan dari 300-700 lux. Dari analisis pengukuran mikroklimat di tempat penelitian pada ruang radiologi IRD RSUP Sanglah dapat dijelaskan sebagai berikut. Gambar redesain pegangan tabung sinar-X yang ergonomis tersaji dalam gambar 3.1

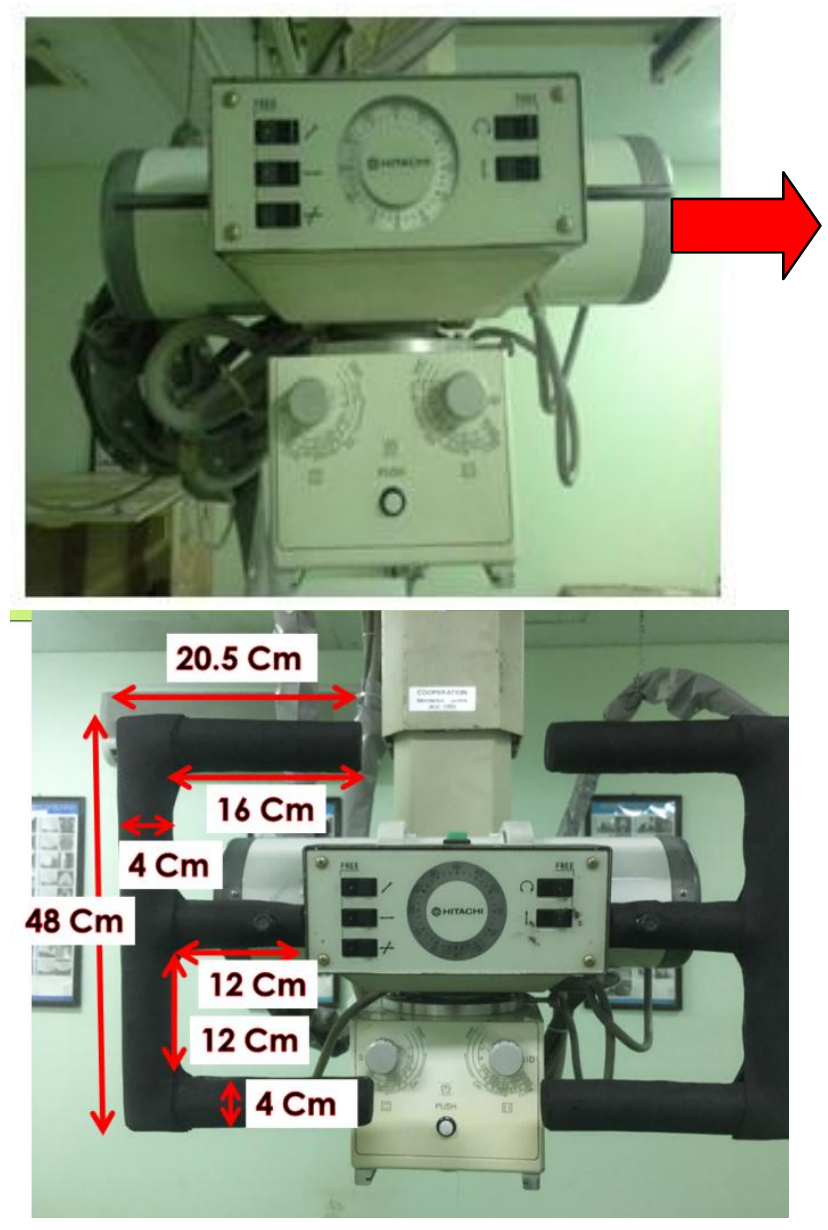

Vol.3, No.2 : 1 Juli-Desember 2017

Gambar 3.1 Redesain pegangan tabung sinar-X dari awal hingga menjadi lebih ergonomis

Hasil pengukuran suhu udara selama penelitian berlangsung didapatkan rentang suhu basah sebelum perbaikan adalah 20 $22^{\circ} \mathrm{C}$ dengan rerata $20.72 \pm 0.66^{\circ} \mathrm{C}$, suhu basah setelah perbaikan adalah $22-21^{\circ} \mathrm{C}$ dengan rerata $20.47 \pm 0.51^{\circ} \mathrm{C}$, dan kelembaban relatif adalah 70,47\%. Suhu kering sebelum perbaikan dengan rentangan $24-26^{\circ} \mathrm{C}$, dengan rerata $24,89 \pm 0,52^{\circ} \mathrm{C}$, dan suhu kering sesudah perbaikan dengan rentangan $24-26^{\circ} \mathrm{C}$ dengan rerata $25.17 \pm 0,56^{\circ} \mathrm{C}$ kelembaban relatif adalah $69,56 \%$. Sukaya (2003) pekerja dapat beradaptasi pada $30,84 \pm 0,69^{\circ} \mathrm{C}$ dan Radiawan (2008) pekerja dapat beradaptasi pada $31,33 \pm 0,57^{\circ} \mathrm{C}$ sedangkan Padmanaba (2005) mengatakan bahwa pekerja dapat beradaptasi pada kondisi $27,16 \pm 1,07^{\circ} \mathrm{C}$.

Suhu udara yang berada diluar atau ruang terbuka adalah daerah nyaman yaitu 22$26^{\circ} \mathrm{C}$ untuk orang Indonesia (Manuaba,1998). Secara umum suhu udara di ruang radiologi IRD RSUP Sanglah Denpasar sebagai tempat penelitian masih dalam batas yang dapat diadaptasi oleh radiografer.

Pengukuran ditempat penelitian didapatkan rentang kelembaban relatif 68$75 \%$ dengan rerata sebelum perbaikan $70,47 \pm 2,79 \%$ dan sesudah perbaikan 69,56+2,90\%. Menurut Soerjani (1987) daerah nyaman untuk orang Indonesia, suhu kering berkisar $22-28^{\circ} \mathrm{C}$ dengan kelembaban 70-80\%. Padmanaba (2005) dalam penelitian mendapatkan kelembaban relatif $70-78 \%$ dengan rerata $72 \pm 0,69 \%$, sedangkan Radiawan (2008) mendapatkan rerata kelembaban relatif $76 \pm 5,77 \%$. Oetojo (1980) menyatakan bahwa 
ISSN Print : 1411 - 951 X, ISSN Online : 20503-1716

Jurnal Ergonomi Indonesia (The Indonesian .Journal of Ergonomic)

indikator suhu yang diperkenankan pada suatu lingkungan kerja adalah antara 21 $30^{\circ} \mathrm{C}$ dengan kelembaban udara $65-95 \%$. Kelembaban udara di tempat penelitian sangat penting untuk dipantau untuk dapat menggambarkan tingkat kejenuhan uap air pada tempat tersebut yang dapat berpengaruh terhadap penguapan keringat dimana semakin lembab keadaan udara maka semakin sulit penguapan keringat. Dari uraian diatas dapat disimpulkan bahwa kelembaban udara secara fisiologi tidak menimbulkan efek negatif terhadap kesehatan, karena kelembaban pada tempat penelitian masih tergolong normal

Pengukuran kebisingan didapatkan rerata 69,39+0,99 dB yang sebagian besar berasal dari bunyi mesin dan percakapan instruksi antar subjek penelitian dengan pasien. Kondisi ini masih termasuk dibawah batas kebisingan yaitu $80 \mathrm{dBA}$ (Mangunwijaya,2000) sehingga tidak sampai mengganggu aktivitas pelayanan radiologi di ruang pemeriksaan radiologi IRD RSUP Sanglah. Disebutkan pula bahwa tidak semua bunyi yang keras atau gaduh dirasakan sebagai gangguan, tergantung dari perasaan dan kebiasaan masing-masing. Dari hasil pemantauan dan pengukuran selama penelitian berlangsung rerata penerangan sebelum perbaikan diperoleh adalah 59,64 $\pm 1,15$ lux dan setelah perbaikan diperoleh rerata 59,58 $\pm 0,87$ lux. Penerangan tersebut dianalisis dengan uji t-paired ternyata tidak berbeda bermakna $(p>0,05)$. Sesuai dengan rekomendasi intensitas penerangan untuk membaca dan menulis adalah 350700 lux (Manuaba 1998b). Hal ini menunjukkan bahwa intensitas penerangan kondisinya nyaman untuk melakukan pemeriksan radiologi dan pelayanan terhadap pasien.
Vol.3, No.2 : 1 Juli-Desember 2017

Sikap kerja radiografer adalah sikap kerja berdiri bervariasi dengan pembobotan dalam waktu tak tentu sesuai dengan pemeriksaan yang dilakukan dan jumlah pasien yang dikerjakan, jika jumlah pasien banyak dengan berbagai pemeriksaan hal ini sering menimbulkan keluhan-keluhan pada beberapa organ tubuh radiografer. Adanya keluhan yang dirasakan oleh radiografer dikarenakan adanya sikap kerja paksa dan kerja dengan postur tubuh yang tidak alamiah. Hal ini juga dibuktikan dalam penelitian Radiawan (2008) yang melaporkan bahwa keluhan muskuloskeletal timbul pada pekerja wanita akibat dari sikap kerja yang kurang baik dan waktu kerja yang cukup lama. Dengan demikian perbaikan sikap kerja yang dilakukan dari posisi berdiri menjadi posisi duduk-berdiri ternyata mampu menurunkan keluhan muskuloskeletal.

Keluhan muskuloskeletal subjek dihitung berdasakan selisih skor dari hasil pengisian kuesioner Nordic Body Map skala Likert pada kontrol dan intervensi berdasarkan empat skala. Semakin tinggi angka skor total keluhan muskuloskeletal maka makin tinggi tingkat keluhan muskuloskeletal pada subjek penelitian. Pada sebelum perbaikan sebelum mulai pemeriksaan menunjukkan rerata $36.93 \pm 3,64$, sesudah adalah $43,86 \pm 3,86$. Pada sesudah perbaikan sebelum mulai melakukan pemeriksaan radiologi adalah $36,50 \pm 3,65$ dan sesudah $38,56 \pm 3,65$. Hasil uji perbedaan efek beda skor sebelum perbaikan dengan sesudah perbaikan dengan uji $t$-paired, menunjukkan $(\mathrm{p}<0,05)$ artinya ada perbedaan secara signifikan. Artinya ada penurunan tingkat keluhan muskuloskeletal sesudah perbaikan yang mencapai 4,57 skor atau $10.42 \%$. 
ISSN Print : 1411 - 951 X, ISSN Online : 20503-1716

Jurnal Ergonomi Indonesia (The Indonesian .Journal of Ergonomic)

Dalam konsep ergonomi prioritas utama adalah menyesuaikan desain dan sistem kerja mesin dengan kemampuan, kebolehan dan keterbatasan manusia (fitting the job to the man) (Grandjean, et al, 2000). Oleh karena itu setiap interaksi manusia dengan mesin harus dirancang sedemikian rupa sehingga terjadi keharmonisan antara daya kerja mesin dengan kemampuan, kebolehan dan keterbatasan pekerja. Radiawan (2008) mengatakan bahwa dengan memperbaiki sikap kerja dan memperbaiki gagang alat penyisitan dapat mengurangi keluhan perajin tikar pandan sebesar $14,51 \%$. Sukaya (2003) menyatakan bahwa perbaikan stasiun kerja dapat mengurangi muskuloskeletal sebesar 13,07\% pada pekerja bagian packing di perusahaan furniture. Dari uraian diatas dapat disampaikan bahwa dengan memperbaiki sikap kerja dan memperbaiki alat yang mengacu kepada antropometri pekerja dapat mengurangi keluhan muskuloskeletal radiografer RSUP Sanglah yang pada akhirnya diharapkan dapat meningkatkan kecepatan pemeriksaan kerja radiografer saat melakukan pemeriksaan radiologi di RSUP Sanglah.

Kelelahan merupakan suatu keadaan sementara yang ditimbulkan oleh aktivitas yang berlebihan atau berkepanjangan yang dimanifestasikan sebagai penurunan fungsi aktivitas, fungsi kapasitas organ, baik pada organ itu sendiri atau seluruh tubuh dan dirasakan secara spesifik sebagai kelelahan umum. Kelelahan adalah salah satu cara dari tubuh mengingatkan bahwa ada persoalan dalam tubuh kita yaitu ketika badan terasa lelah barulah disadari bahwa ada penyebab yang harus dihilangkan.
Vol.3, No.2 : 1 Juli-Desember 2017

Kelelahan harus ditangani dengan baik, karena kelelahan yang berkepanjangan akan dapat menurunkan produktivitas pekerja. Kelelahan pada radiografer ini dipengaruhi oleh beberapa faktor seperti (1) task yaitu penggunaan alat radiologi yang memiliki bobot berat; (2) organisasi kerja, yaitu waktu kerja dalam sehari, rotasi antar pekerja dan waktu kerja dalam sebulan; (3) lingkungan kerja yang sarat dengan medan radiasi pengion, lingkungan biologis dan kimia dalam rumah sakit; (4) faktor ergonomi dan sikap kerja; (5) faktor sosial budaya subjek sendiri. Berdasarkan hasil penelitian didapatkan bahwa rerata kelelahan umum setelah bekerja sebelum perbaikan adalah 59,29 $\pm 2,74$ dan setelah perbaikan adalah 45,32 $\pm 3,50$. Analisis kemaknaan dengan uji t-paired menunjukkan bahwa kedua kelompok sesudah bekerja melakukan pemeriksaan radiologi, rerata kelelahannya berbeda secara bermakna $(\mathrm{p}<0,05)$ dengan penurunan keluhan umum sebesar 13.27 atau $22.38 \%$.

Terjadinya peningkatan kelelahan selama bekerja disebabkan karena beberapa faktor yaitu keluarnya energi selama bekerja dan juga adanya pengaruh lingkungan seperti medan radiasi pengion, temperatur, kelembaban relatif, dan gerakan udara. Seseorang memerlukan energi tertentu untuk menjaga fungsi tubuh dan ketika bekerja fisik kebutuhan energi meningkat. Sedangkan penurunan skor kelelahan disebabkan oleh implementasi ergonomi yang diterapkan setelah perbaikan redesain. Implementasi tersebut yaitu redesain pegangan tabung sinar-X yang telah disesuaikan dengan antropometri radiografer. Penelitian ini sejalan dengan penelitian Santosa (2013) terhadap pemakaian alat pengaduk dodol yang 
ISSN Print : 1411 - 951 X, ISSN Online : 20503-1716

Jurnal Ergonomi Indonesia (The Indonesian .Journal of Ergonomic) ergonomis pada perajin dodol wanita di desa Penglatan Buleleng bahwa terjadi penurunan tingkat kelelahan sebesar 22,09 $\%$. Penelitian ini didukung juga oleh temuan Adiatmika (2007) yang mengatakan bahwa kondisi kerja dengan pendekatan ergonomi total dapat menurunkan kelelahan 6,79\%. Penelitian hampir sama juga dilakukan oleh Sundari (2008) mengatakan bahwa intervensi ergonomi pada proses pengolahan tanah bahan keramik dapat mengurangi kelelahan sebesar 60,98\% Berdasarkan hasil penelitian, hasil analisis menunjukkan setelah meredesain alat kerja terjadi penurunan kelelahan umum sebesar $25,91 \%$, dan perbedaannya bermakna ( $<<0,05)$. Hal ini disebabkan karena pegangan tabung sinar- $X$ dengan desain yang baru ini dapat memberikan kenyamanan dalam bekerja sehingga tidak ada sikap paksa atau tidak fisiologis disaat bekerja yang dapat mengurangi energi yang keluar. Dengan demikian, dapat dikatakan bahwa aplikasi ergonomi pada redesain pegangan tabung sinar- $X$ yang mengacu pada aspek antropometri dengan penyesuaian ukuran genggaman terbukti mengurangi kelelahan umum.

Dari hasil analisis data diperoleh rerata kecepatan pemeriksaan sebelum perbaikan diperoleh rerata waktu pemeriksan adalah $248 \pm 8,84$ detik per pemeriksaan dan sesudah perbaikan $217 \pm 6,52$ detik per pemeriksaan berbeda bermakna $(\mathrm{p}<0,05)$ terjadi peningkatan kecepatan pemeriksaan berupa penyingkatan waktu pemeriksaan sebesar 31 detik kerja. Dengan perbaikan desain pegangan tabung sinar-X yang ergonomis pada alat radiologi di RSUP Sanglah Denpasar dapat meningkatkan kecepatan pemeriksaan kerja sebesar $12,50 \%(\mathrm{p}<0,05)$. Didukung oleh
Vol.3, No.2 : 1 Juli-Desember 2017

penelitian Radiawan (2008) melaporkan modifikasi alat penyisitan pandan yang disesuaikan dengan antropometri tangan perajin dapat meningkatkan produktivitas sebesar 15,90\% ( $\mathrm{p}<0,05)$. Begitu pula dalam penelitian Murniasih (2004) tentang modifikasi gagang pisau yang disesuaikan dengan antropometri tangan tukang tues dapat meningkatkan produktivitas sebesar $11,21 \%$ ( $\mathrm{p}<0,05$ ). Putra(2004) menyatakan bahwa dengan memperbaiki sikap kerja dan penambahan spon pada gagang gergaji kayu mengalami peningkatan produktivitas sebesar 48,72\%. Dengan demikian perbaikan alat kerja dan sikap kerja dapat meningkatkan kecepatan pemeriksaan radiografer dan produktivitas pekerja.

\section{Simpulan dan Saran}

\subsection{Simpulan}

Dari hasil dan pembahasan penelitian dapat disimpulkan sebagai berikut Redesain pegangan tabung sinar-X yang ergonomis dapat menurunkan keluhan muskuloskeletal 10,42\% ( $\mathrm{p}<0,05)$, mengurangi keluhan umum sebesar 22,38\%, meningkatkan kecepatan pemeriksaan sebesar $12,50 \%(\mathrm{p}<0,05)$ pada radiografer di Instalasi Radiologi RSUP Sanglah Denpasar.

\subsection{Saran}

Berdasarkan simpulan hasil penelitian maka disarankan sikap kerja paksa pada pemeriksaan radiologi akan mengakibatkan rasa sakit dan tidak nyaman setelah bekerja, maka diperlukan konsultasi dengan ergonom agar keluhan tersebut tidak menimbulkan sakit akibat kerja berlanjut. Bagi Rumah Sakit atau penanggung jawab instalasi dalam usaha meningkatkan kesehatan dan kesejahteraan 
ISSN Print : 1411 - 951 X, ISSN Online : 20503-1716

Jurnal Ergonomi Indonesia (The Indonesian .Journal of Ergonomic)

pekerja secara umum, maka untuk aktivitas pelayanan radiologi disarankan supaya dilengkapi dengan fasilitas atau peralatan yang ergonomis agar radiografer dapat memberikan pelayanan dan pemeriksaan radiologi dengan lebih nyaman dan sehat. Produsen alat-alat radiologi seperti pesawat sinar-X dan alatalat bantu pemeriksaan radiologi agar mempertimbangkan aspek ergonomis sebagai salah satu unsur produksi, sehingga membantu sosialisasi bekerja aman dan nyaman serta hidup sehat. Bagi peneliti lain disarankan untuk meneliti lebih jauh masalah bau kimia obat-obatan dan cairan pencucian film yang dihadapi radiografer pada saat melakukan pelayanan dan pemeriksaan radiologi.

\section{Daftar Pustaka}

Arrowsmith. "The Prevalence of WorkRelated Upper Limb Disorders Amongst Radiographers." Synergy (Synergy), September 2000.

Feather, C. "WRMSD: An occupational hazard for sonographers." Synergy, 2001

Grandjean, E. 2000, Fitting the Task To the Man, A Texbook of occupational Ergonomic Edition London, Taylor \& Fancis.

Mangunwijaya, Y.B. 2000. Pengantar Fisika Bangunan: Jakarta, Djembatan.

Manuaba, Ida Bagus Adnyana. "Ergonomi, Kesehatan dan Keselamatan Kerja. Dalam: Wignyosoebroto, S.\& Wiratno, S.E.,Eds." Proceeding Seminar Nasional Ergonomi. Surabaya: PT Guna Widya, 2000. Murniasih, N. 2004 Modifikasi Pisau Metetuesan dan Perbaikan Sikap Kerja Dapat Menurunkan Keluhan Subyektif serta Peningkatkan Produktivitas Kerja Tukang Tues. (Tesis) Denpasar. Program Magister Ergonomi-
Vol.3, No.2 : 1 Juli-Desember 2017

Fisiologi Kerja, Program

Pascasarjana Universitas

Udayana.

Nala, I.G.N. 1994. Perbedaan Kekuatan Otot Tangan Absolut dan Relatif antara Siswa-siswi SMP dengan Siswa-siswi SMA di Denpasar. Disajikan dlama Kongres VI dan Seminar Nasional VII IAIFI. Surabaya: 18-20 November

Nasir, M. 2003. Metode Penelitian. Jakarta: Ghalia Indonesia

New York; McGraw-Hill Book Company.

Oetojo, 1980. Pedoman Penggunaan Alatalat Deteksi Pengawasan Kesehatan Kerja. Jakartaa; dirjen Pembinaan Hubungan Perburuhan dan Perlindungan Tenaga Kerja, adepnakera\& Transmigrasi RI.

Oetojo, 1980. Pedoman Penggunaan Alatalat Deteksi Pengawasan Kesehatan Kerja. Jakartaa; dirjen Pembinaan Hubungan Perburuhan dan Perlindungan Tenaga Kerja, adepnakera\& Transmigrasi RI.

Padmanaba, C.G.R. 2005. Penambahan Penerangan Lokal pada Meja Gambar Mengurangi Keluhan Subjektif dan Meningkatkan Produktivitas Kerja Mahasiswa Desain Interior (Tesis), Denpasar: Program Pascasarjana Universitas Udayana.

Radiawan, 2008. Perbaikan Alat Kerja dan Cara Kerja Penyisitan Pandan Menurunlan Keluhan Muskuloskeletal dan Kelelahan Serta Meningkatkan Produktivitas Perajin Tikar Pandan Di Desa Tumbu Karangasem (Tesis) Denpasar: Program Magister Ergonomi-Fisiologi Kerja, Program Pascasarjana Universitas Udayana.

Russo, A, C Murphys, V Lessoway, and J Berkowitz. "The prevalence of 
ISSN Print : 1411 - 951 X, ISSN Online : 20503-1716

Jurnal Ergonomi Indonesia

(The Indonesian .Journal of Ergonomic)

musculoskeletal symptoms among

British Columbia Sonographers.

Applied Ergonomics 2002; 33:385-

93." British Columbia

Sonographers. Applied Ergonomics

2002; 33, 2002: 385-93.

Sastrowinoto, S. 1985. Meningkatkan

Produktivitas dengan Ergonomi. Jakarta:

PT.

Sukaya, 2003. Perbaikan Stasiun Kerja

Mengurangi Beban Kerja dan

Keluhan Muskuloskeletal serta

Meningkatkan Produktivitas Kerja

Pekerja Packing pada Perusahaan

Furniture Sidakarya Denpasar.

(Tesis) Denpasar: Program

Magister Ergonomi-Fisiologi

Kerja, Program Pascasarjana

Universitas Udayana.

Sutajaya, M. 2006. Manfaat Praktis

Ergonomi. Kerjasama Bagian Faal

Fakultas Kedokteran Universitas

Udayana Dengan Jurusan

Pendidikan Biologi Fakultas

Pendidikan MIPA Universitas

Pendidikan Ganesha Singaraja Bali.

Denpasar: Bagian Faal Fakultas

Kedokteran Universitas Udayana. 